INTERNATIONAL

FOOD POLICY

RESEARCH

INSTITUTE

IFPRI

IFPRI Discussion Paper 01646

May 2017

Intertemporal Choice and Income Regularity

Non-Fungibility in a Lab-in-the-Field Experiment

Berber Kramer

David Kunst

Markets, Trade and Institution Division 


\section{INTERNATIONAL FOOD POLICY RESEARCH INSTITUTE}

The International Food Policy Research Institute (IFPRI), established in 1975, provides evidence-based policy solutions to sustainably end hunger and malnutrition and reduce poverty. The Institute conducts research, communicates results, optimizes partnerships, and builds capacity to ensure sustainable food production, promote healthy food systems, improve markets and trade, transform agriculture, build resilience, and strengthen institutions and governance. Gender is considered in all of the Institute's work. IFPRI collaborates with partners around the world, including development implementers, public institutions, the private sector, and farmers' organizations, to ensure that local, national, regional, and global food policies are based on evidence.

\section{AUTHORS}

Berber Kramer (b.kramer@,cgiar.org) is a research fellow in the Markets, Trade and Institutions Division of the International Food Policy Research Institute, Washington, DC.

David Kunst is a PhD candidate in the Labor, Health, Education and Development Research Group of Tinbergen Institute and VU Amsterdam.

\section{ABSTRACT}

Motivated by evidence of mental accounting, this paper tests whether the choice of when to be paid depends on the income type. A lab-in-the-field experiment in Kenya asked dairy cooperative members to allocate both their regular milk payments and an irregular windfall between two dates. We find that participants allocated milk payments to the later of the two dates but allocated the windfall to the earlier date. Most participants self-reported deferring their milk payments in order to save for lump-sum expenses. Those planning to use milk payments for smaller, more frequent purchases were less likely to defer payments. Farmers hence appeared to earmark regular milk payments, but not the irregular windfall, for bulky expenditures. This behavior potentially explains why discount rates elicited using experimenter money are often higher than those inferred from observed choices over regular income. Given that compliance with informal contracts depends on whether the timing of payments aligns with recipient preferences, these findings also have implications for contract design in rural value chains.

\footnotetext{
Notices

${ }^{1}$ IFPRI Discussion Papers contain preliminary material and research results and are circulated in order to stimulate discussion and critical comment. They have not been subject to a formal external review via IFPRI's Publications Review Committee. Any opinions stated herein are those of the author(s) and are not necessarily representative of or endorsed by the International Food Policy Research Institute.

${ }^{2}$ The boundaries and names shown and the designations used on the map(s) herein do not imply official endorsement or acceptance by the International Food Policy Research Institute (IFPRI) or its partners and contributors.

${ }^{3}$ Copyright remains with the authors.
} 


\title{
Intertemporal Choice and Income Regularity: Non-Fungibility in a Lab-in-the-Field Experiment
}

\author{
Berber Kramer* David Kunst ${ }^{\dagger}$
}

This version: May 25, 2017

\begin{abstract}
Motivated by evidence of mental accounting, this paper tests whether the choice of when to be paid depends on the income type. A lab-in-the-field experiment in Kenya asked dairy cooperative members to allocate both their regular milk payments and an irregular windfall between two dates. We find that participants allocated milk payments to the later of the two dates but allocated the windfall to the earlier date. Most participants self-reported deferring their milk payments in order to save for lump-sum expenses. Those planning to use milk payments for smaller, more frequent purchases were less likely to defer payments. Farmers hence appeared to earmark regular milk payments, but not the irregular windfall, for bulky expenditures. This behavior potentially explains why discount rates elicited using experimenter money are often higher than those inferred from observed choices over regular income. Given that compliance with informal contracts depends on whether the timing of payments aligns with recipient preferences, these findings also have implications for contract design in rural value chains.
\end{abstract}

JEL: D03, Q13, O12.

Keywords: time preferences, mental accounting, fungibility, collective marketing.

\footnotetext{
* Markets, Trade and Institutions Division, International Food Policy Research Institute (IFPRI). Email: b.kramer@cgiar.org.

${ }^{\dagger}$ Tinbergen Institute and VU Amsterdam. Email: d.m.kunst@vu.nl.

This work was undertaken as part of the CGIAR Research Program on Policies, Institutions, and Markets (PIM) led by the International Food Policy Research Institute (IFPRI). We gratefully acknowledge funding from IFPRI's Strategic Innovation Fund for Associate Research Fellows and we thank the COVDA team (Edward Yano, Stephen Mutwol, Janet Jepkosgei and Josephine Seurey) for their tremendous dedication to data collection. We received valuable comments and suggestions from Glenn Harrison, Remco Oostendorp, Peter Lanjouw, seminar participants at IFPRI, the VU Amsterdam, as well as participants in the 2016 CEAR-CSAE workshop "Eliciting Subjective Beliefs and Risk and Time Preferences in Developing Countries" and the CSAE Conference 2017.
} 


\section{Introduction}

Institutions such as cooperatives, producer groups, and contract farming arrangements can help smallholder farmers reduce their transaction costs and improve productivity. These aggregators generate economies of scale by bulking output from many small producers, which can improve prices, stability, and access to inputs (Reardon et al., 2009). However, they typically rely on informal contracts that are difficult to enforce (Minot and Sawyer, 2014), especially if their timing of payments does not align with farmers' needs. They tend to defer payments, potentially reducing compliance among farmers in need of cash (Vargas Hill et al., 2015, Geng, Kramer and Janssens, 2017). At the same time, farmers may actually prefer deferred payments in order to save (Casaburi and Macchiavello, 2016). The optimal design of informal contracts in agricultural value chains hence depends not only on how much farmers are paid but also on when they prefer to be paid.

Lab-in-the-field experiments on intertemporal choice can help elicit preferences for when to be paid (Harrison and List, 2004; Andersen et al., 2008). However, most such experiments find an anomalously high demand for smaller-sooner as opposed to larger-later rewards. Discount rates measured in experiments are often too high to reconcile with those inferred from observed savings rates (Frederick, Loewenstein and O'Donoghue, 2002 , Camerer et al. 2015). Individuals sometimes even prefer deferred payments, for instance through a "13th salary" at the end of the year, committed savings devices with negative real interest rates (Ashraf, Karlan and Yin, 2006; Bryan, Karlan and Nelson, 2010), and reduced payment frequencies for regular income (Casaburi and Macchiavello, 2016).

This paper aims to reconcile these seemingly conflicting findings by means of a labin-the-field experiment with dairy farmers in Kenya. Motivated by evidence of mental accounting, we hypothesize that individuals are more patient regarding regular income payments than regarding windfall payments. Mental accounts may govern decisions over 
regular income, but such accounts will not exist for unusual income (Thaler, 1999). Further, for windfall gains, reference-dependent theories of intertemporal choice predict handto-mouth consumption, although individuals prefer to maintain the status quo for already planned income paths (Kőszegi and Rabin, 2009, Kramer, 2016). Moreover, once individuals form a habit of deferring payments, they will prefer to keep doing so (Duesenberry, 1952, Bowman, Minehart and Rabin, 1999), but they will have formed such habits only for regular income types. Payments from regular income sources may also be more visible and potentially controlled by other household members, so that individuals may want to set them aside by deferring payments, whereas it is easier to hide and keep a windfall. Each of these mechanisms predicts more patient choices for more regular income types.

Our experiment tests this prediction for members of a dairy cooperative that defers milk payments until the next month. We asked participants to allocate their milk income between this deferred payment date and an earlier date within the next week. We also asked the same participants to allocate an irregular type of income, namely a gift for participating in the study, between an earlier and a later payment date. The vast majority of participants preferred to defer milk payments until the next month. In contrast, the same participants rarely chose to defer the gift to the later payment date. This gap between the two types of intertemporal allocations cannot be explained by differences in front-end delays, the magnitude of experimental stakes, trust, or transaction costs.

Participants self-reported deferring the milk payment in order to save for lump-sum expenditures such as agricultural inputs or school fees, instead of being tempted to spend their dairy income on something else. The preference for deferred milk payments was weaker for participants who planned to spend their milk payment on more frequent, smaller expenditures such as food and other daily needs. Our findings are thus consistent with participants' having established mental accounts that govern how they allocate and spend 
a very regular type of income (the milk payments), whereas they have not developed such mental accounts for an irregular income type (an experimental gift).

This paper relates to three strands of the literature. First, it relates to the literature on income accounting (Thaler, 1990, 1999), meaning that different types of income are labeled differently in spending and saving decisions. Empirically, spending decisions are often inconsistent with the treatment of income types as fully fungible. For instance, child clothing expenditures are more sensitive to changes in child allowances than to changes in other income (Kooreman, 2000). Male farmers in Ivory Coast increase spending on public goods that benefit the entire household after a positive shock to yam income, but purchase prestige goods after a positive shock to income from cash crops (Duflo and Udry, 2004). In Villa, Barrett and Just (2011), agricultural income is treated as not fully fungible. Even labor supply responds differently to windfalls than it does to variation in regular income (Dupas, Robinson and Saavedra, 2016). We provide experimental evidence for non-fungibility in preferences for when to be paid.

Second, we contribute to the literature on linkages between rural output and financial markets. In rural output markets, producers can sell to distant processors at potentially higher prices than those offered in the local market, but often they can do so only by marketing their output collectively through cooperatives, producer groups, and contract farming arrangements. Such institutions typically defer farmers' payments. 11 Geng, Kramer and Janssens (2017) showed that this practice makes collective marketing less interesting from the perspective of cash-constrained farmers. Nonetheless, Casaburi and Macchiavello (2016) found that farmers also value the possibility of saving their money with a trustworthy cooperative, making cooperatives that can be trusted to defer payments more interesting from the perspective of farmers. Consistent with this latter result, our participants appear

\footnotetext{
${ }^{1}$ In the case of cooperatives and other producer groups, this deferral is likely due to liquidity constraints that force the producer groups to wait until they have received their payment from processors. Under contract farming arrangements, payments may be delayed due to the number of administrative steps.
} 
to use the cooperative to save their regular milk payment. We further show that this finding does not generalize to irregular windfalls, meaning that our sample is not more patient than the standard subject pool in experiments on intertemporal choice. Thus, our findings highlight the importance of the type of income for which preferences are elicited.

Third, we contribute to the empirical literature on the stability of intertemporal allocations of income. Several studies (for example. Meier and Sprenger, 2015; Chuang and Schechter, 2015, Halevy, 2015, Janssens, Kramer and Swart, 2017) have experimentally estimate discount rates for the same individuals at different points in time. They have found evidence of instability in time preferences over time, in part due to random noise in decision making and in part due to liquidity constraints. Ubfal (2016) showed that the commodity in which income is paid influences discount rates, resulting in domain-specific time preferences. Like the present study, each of these papers keeps constant individual characteristics that may influence intertemporal allocations, but these other papers analyze only choices regarding windfall gains and do not consider more regular types of income.

The remainder of this paper is structured as follows. The next section describes the study context and participant sample. Section 3 presents the experimental methods and procedures. Section 4 summarizes farmers' intertemporal allocations of gift and milk payments, and discusses possible interpretations of our results. The final section concludes.

\section{Study setting}

\subsection{Context}

The experiment was conducted with dairy farmers who supply milk to Metkei Dairies Ltd., a farmer-owned dairy hub in the Rift Valley region in western Kenya. Metkei collects milk from 1,000 to 1,500 dairy farmers, cools the milk in two cooling centers, and sells it to larger processing companies. Metkei receives milk twice per day: once in the morning and 
once in the afternoon. In the morning, farmers can either deliver the milk themselves to one of the two cooling plants or deliver via a Metkei transporter who passes from village to village and collects the milk at the farmgate for a small deduction from the milk price. In the afternoon, no central transport is available, making afternoon delivery feasible only for farmers who live close enough to a cooling plant to deliver the milk themselves. Farmers have no cooling facilities and cannot store milk produced in the afternoon for the next morning's milk collection.

Outside Metkei, farmers can sell their milk to neighbors and traders who serve local (informal) markets. It is common to send the morning milk to Metkei and keep the afternoon milk for consumption and sale in the local market. Buyers in the local market do not formally test milk quality and tend to pay cash on delivery to any household member who sells the milk. In contrast, Metkei tests whether the milk density is in an acceptable range (as an indicator of quality), pays only once per month, and pays only the supplier registered with Metkei (often the male household head). Payments are typically deferred until the 11th of the next month because that is when the monthly payment from the processing company is on the way. Finally, Metkei prices vary from month to month, whereas local market prices can vary from day to day. During the main period of interest, the market was paying farmers a higher price (net of transportation costs) compared with Metkei.

One explanation for why farmers sell to Metkei, despite opportunities to receive a higher price for milk sold in the local market, is that Metkei provides other valuable services. Farmers can, for instance, purchase veterinary services, animal feed, fertilizers, and other inputs from Metkei. They can choose to pay for these services inkind, meaning that costs are deducted from the next milk payment. There are no charges for taking out these in-kind advances. Prior to our study, 43 percent of participants planned to use their milk account for such services in the next eight weeks. Few farmers, however, reported the possibility of 
in-kind payment for services as the main reason for delivering their milk to Metkei.

Further, Metkei provides farmers with a means to save money. In our sample, 66 percent of dairy farmers reported selling to Metkei rather than other buyers because Metkei can be trusted more to save money for later. The deferred milk payments are the main way through which these farmers save. Although they can request advance payments for up to 50 percent of the milk delivered in a given month from the 21 st of that month onwards, these advances are costly. In order be paid three weeks before the regular payment date, farmers are charged a 7.5 percent interest rate 2 By discouraging farmers from taking out advances unless they really need the money and are willing to pay the high fees, the milk account with Metkei acts as a commitment savings device.

Administrative data nonetheless indicate that 35 percent of all Metkei farmers took out an advance at least once between January and September 2015, and for those who did, advance payments accounted for more than 30 percent of the total monthly milk payment (or 60 percent of the amount that farmers could take out as an advance). Further, 28 percent of participants reported having taken advances during the eight weeks prior to our study, mostly to pay for school fees and emergencies. More than half said they needed this money urgently and could not have gotten it elsewhere. A priori, we would therefore expect a high demand for early milk payments.

\subsection{Sampling}

Looking for ways to improve its services and attract more milk, Metkei was interested in measuring farmers' demand for early milk payments. To that end, we sampled study participants using the following procedures. First, from all farmers to whom Metkei made a payment in September 2015, we omitted the 2 percent who delivered, on average, more

\footnotetext{
${ }^{2}$ Without compounding, this is equivalent to an annual interest rate of 130 percent, and compounding would result in an even higher annual interest rate.
} 
than 25 kilograms of milk per day. This group included a few larger farmers who collect milk from other farmers under their own supplier number, and who should therefore be omitted from the sampling frame, as well as large farmers to whom Metkei was not ready to offer weekly payments because they were not expected to be as cash constrained as smaller farmers. For logistical reasons, we then selected all farmers who self-delivered to one of the collection points, and all farmers who delivered through one of the three largest transporters ${ }^{3}$ This procedure left us with a sampling frame of 533 farmers.

Initially, we planned to randomly select 240 farmers from the set of 313 farmers who selfdelivered to Metkei in September 2015, and another 120 farmers from the 220 who delivered via a transporter, both stratified by whether the total quantity of milk delivered to Metkei was above or below the median. The remaining farmers would be kept as replacements. However, once we started the interviews with self-delivery farmers, it turned out to be very challenging to find many of these farmers, because Metkei did not always have up-to-date phone numbers. In order to still include 360 households in the study, we decided to conduct interviews with all of the farmers we could locate from the 533 farmers in the sampling frame. We worked with milk transporters and staff at the Metkei collection centers to locate as many dairy farmers as possible. The enumerators were able to conduct first interviews with 64 percent of the self-deliverers and 74 percent of the transporter deliverers in the sampling frame. In total, they conducted first interviews in 363 households.

The study interviewed households twice. In the first round in November-December 2015, it targeted the person responsible for the decision of where to sell milk. If a different person was selling the afternoon milk and stated interest in delivering this milk to Metkei, we conducted an interview with that person as well. During the first round of interviews, there were only 11 such afternoon suppliers, resulting in a sample of 374 first-round partici-

\footnotetext{
${ }^{3}$ In this way, we could focus on a confined geographic area and allow enumerators to follow the transporters on their route, which simplified survey logistics.
} 
pants. In the second round in February-March 2016, enumerators were able to interview 90 percent of first-round participants. They also interviewed an additional 28 suppliers from the same households who had not been included in the first round, for instance because they were not interested in delivering their milk to Metkei. As a result, the second round included 355 participants. Appendix Table A2 summarizes response rates and attrition in both rounds.

\subsection{Participant Characteristics}

Table1 1 describes participant characteristics. Panel A provides demographic characteristics for all study participants included in the analyses ${ }^{4}$ Panels B and $\mathrm{C}$ summarize time-varying characteristics during the first and second round, respectively. Columns (1) and (2) present statistics for all participants in a given round. Columns (3) and (4) provide summary statistics for the sample of 327 suppliers who participated in both rounds. Column (5) tests for statistically significant differences between the full sample and the balanced panel included in both rounds.

The average participant was 45 years old and had around 14 years of experience with dairy farming. Fewer than half of the participants were women. Because only the second round includes additional household members-predominantly female--who sold their milk outside Metkei, the share of women is lower in the sample of participants interviewed in both rounds than in the full sample $(p<0.10) I^{5}$ Nearly 80 percent of participants had completed primary school but less than half has completed secondary school. For the vast majority, dairy farming was the main daily activity and the main source of income, often

\footnotetext{
${ }^{4}$ We excluded six first-round and four second-round respondents from the analyses for reasons outlined in Appendix Table A2

${ }^{5}$ In Kenya as well as other parts of eastern Africa, dairy farming is traditionally a female income-generating activity, but men have become increasingly involved as dairy farming has become more commercialized. Our share of female farmers is relatively low compared with the samples of other studies because we targeted the participants in the household who were in charge of making decisions about milk income, not necessarily those spending most time on activities related to dairy farming.
} 
along with crop farming.

During the first round, a few participants (18 percent) reported delivering afternoon milk to Metkei. Participants had on average fewer than three lactating cows and produced around 13 kilograms of milk on the day prior to the interview. They reported using this milk mainly for home consumption (48 percent), or supplying it to Metkei (46 percent). Participants reported selling only a small share ( 5 percent) of their milk to other buyers. This is much lower than in other studies, potentially due to underreporting of side-selling. Indeed, based on administrative data from Metkei on suppliers' daily deliveries, farmers delivered only 36 percent of their self-reported production to Metkei on the day prior to the interview. Thus, farmers overstated the share delivered to Metkei by about 10 percentage points. During the first round, Metkei offered on average KSh 33.7 per kilogram of milk, net of milk transportation costs. This was KSh 1.7 higher compared to milk prices in the local market 6

From the first to the second round, we observe a reduction in the proportion of participants who reported selling their afternoon milk to Metkei, especially among the balanced sample that participated in both rounds. The number of lactating cows and amount of milk produced did not change substantially. Self-reported side-selling was higher in the second-round sample than in the first-round sample, but not for the sample participating in both rounds, because side-selling was reported more frequently among household members added in the second round. Nevertheless, the quantity of milk delivered to the cooperative increased between the two rounds due to a reduction in milk consumption. In December, many households have children at home. In the months afterward, these children go back to (boarding) school, resulting in substantially lower milk consumption. In addition, during the second round, Metkei was no longer offering a higher price; partic-

\footnotetext{
${ }^{6}$ This price gap is larger when prices are figured without deducting transportation costs. Transportation costs for milk delivered to Metkei are on average higher than the transportation costs for milk sold in the local market.
} 
ipants reported receiving about a KSh 3 (11 percent) higher milk price when selling their milk outside of the cooperative.

\section{Experimental Design}

The experiment elicited study participants' preferred allocations of milk payments between an earlier and a later date. During the first round, we elicited farmers' preferences for when to receive their milk payments. In the second round, we asked farmers to allocate both their regular milk payments and an irregular gift between earlier and later payment dates, creating within-subject variation in preferences for when to be paid different types of income. The main analyses focus on this second round in order to maximize comparability of the two allocation types. First-round allocations will be presented later as a robustness check.

\subsection{Main Experimental Tasks: Allocation of Milk Payments in Round 2}

During the second round, we asked study participants to make the following decision, for each of the four weeks after the interview:

"For milk delivered between Friday ... [start date] and Thursday ... [end date], which is ... [one, two, three, or four] weeks from now, for how many kilograms of milk do you prefer to be paid at the end of that week?"

Thus, farmers indicated for how much of the milk delivered between Friday and Thursday they preferred to receive a payment on the subsequent Friday. The remainder would be paid on the later, standard payment date, with both the early and the later payments maintaining the Metkei milk price prevailing at the time of delivery. Figure 1 illustrates a timeline for two example interview dates. A participant interviewed on January 30 allocated milk delivered in the week of February 1 (and the weeks of February 8, 15, and 
22) between an early payment on February 8 (and February 15, 22, and 29) and a later payment on March 11. Likewise, if interviewed on February 11, the farmer allocated milk payments from the week of February 12 (or February 19th) between an early payment on February 19 (or February 26) and a later payment on March 11, and milk from the week of February 26 (or March 3) between an early payment on March 3 (or March 10) and a later payment on April 11.

Metkei handled both payments. To reduce transaction costs associated with receiving an extra (early) payment, participants could choose to receive this payment via mobile money or at the collection point, whichever was more convenient for the participant. Farmers were used to receiving their monthly (later) payments through the collection point or transporter. We did not deviate from this approach.

In order to ensure that farmers could still take out in-kind advances for other services, Metkei restricted the maximum weekly payment to 50 percent of the total quantity delivered in a given week. This is consistent with the rule for regular cash advances that farmers were familiar with (although we emphasized that the weekly payments were free of charge, as opposed to the advance payments). Hence, our weekly payment to the farmer was either a payment for the farmer's desired amount of milk or, for farmers who delivered less than 50 percent of the desired amount of milk, a payment for 50 percent of the milk delivered throughout the previous week 7

\subsection{Main Experimental Tasks: Allocation of the Gift in Round 2}

During the same interview, participants were also asked to allocate a gift of KSh 250, approximately US\$2.50, or half the budget in the median farmer's milk payment allocations)

\footnotetext{
${ }^{7}$ We dropped this restriction for a few farmers who delivered only afternoon milk to Metkei, because most farmers were not used to delivering their afternoon milk to Metkei and using it to pay for Metkei services. For them, we maintained 100 percent of expected milk production as the effective budget in allocations of milk payments between the earlier and the later, standard payment date. Results are robust to the inclusion or exclusion of this sample, and to recoding their effective milk budget to 50 percent of expected milk production.
} 
between the Friday of the same week and the Friday three weeks later (see the bottom row labeled "Gift" in both examples from Figure 1). Both payments were made via mobile money. Farmers received an extra KSh 65 on both dates regardless of their choice:

"In addition to the KSh 65 that we are sending you both ... [early date] (this Friday) and ... [later date] (Friday three weeks from now), how much out of KSh 250 do you prefer to receive this Friday?"

Similar to the allocations of milk payments, the allocation of the gift involved a linear budget, without return or penalty on deferred payments. Hence, a standard model with discounting of future income predicts that participants will prefer to have both types of income to be paid on the early date. Further, the number of days between the early and the late payment date was 21 days, comparable to the median delay in the milk payment 8 All allocations were elicited by our enumerators, and payments on the earlier date were mostly done via mobile money $!^{9}$ Finally, because preferences were elicited from the same farmers during the same interview, our findings are not driven by differences in participant characteristics, changes in background wealth, or time-varying preferences. This approach also rules out liquidity constraints as an explanation for differences in intertemporal choice across types of income (in contrast to, for example Dean and Sautmann, 2016 and Janssens, Kramer and Swart, 2017).

Choices also differed in a number of aspects. First, the front-end delay for the gift ranged from 1 to 7 days, whereas the shortest front-end delays for milk payment allocations ranged between 8 and 14 days 10 Second, the gift was only half the value of the weekly

\footnotetext{
${ }^{8}$ The delay of the milk payment, however, ranged from 7 to 35 days, depending on the number of days until the next regular payment date. Because regular payments are made on the 11th of the next month, the regular payment date for milk delivered toward the end of a month comes much sooner than the regular payment date for milk delivered at the beginning of a month.

${ }^{9}$ All participants had access to a mobile money account with M-Pesa, the largest mobile money provider in Kenya.

${ }^{10}$ The front-end delay is the number of days between the interview and the early payment date. For interviews conducted on a Thursday, the first week would start on Friday and the first possible weekly payment would take place on the next Friday, 8 days later. Interviews conducted on a Friday had the longest front-end delay: the first
} 
milk budget that the median farmer could allocate over time, resulting in substantially lower experimental stakes for the gift. Third, the gift was sent via mobile money, but the later milk payment was collected in cash from the collection point, and participants could choose to receive their weekly milk payment in the same way. Choosing also to receive weekly payments at the collection point could create additional transaction costs related to more frequent travel. We had to apply these procedures for practical reasons. We will show that our results are robust to controlling for these differences in front-end delays, experimental stakes, and potential transaction costs.

\subsection{Experimental Tasks Used as a Robustness Check: Round 1}

During the first round, the experiment elicited a number of milk payment allocations as well, which we use as a robustness check. These allocations differ from second-round allocations in a number of respects. To start, participants allocated a payment between the end of the week and the 11th of the next month for two weeks instead of one week at a time. This means that every allocation applies to a two-week period instead of only one week.

Further, first-round allocations varied the return on deferred payments by varying the price for milk that participants chose to be paid for on the earlier payment date. Given that the price for milk paid on the regular (later) payment date was fixed at the prevailing Metkei price, a decrease in the earlier milk price increases the return on deferred payments. In first-round allocations, the earlier milk price was either (1) identical to the prevailing Metkei price, that is, a zero return on deferring payments; (2) KSh 2 (about 7 percent) higher, that is, a negative return on deferring payments; or (3) KSh 2 lower, that is, a positive return on deferring payments. All first-round participants made choices for each

week would start on the subsequent Friday, and the first weekly payment would therefore be made on the Friday 14 days later. For the gift payment, the front-end delay was shorter. However, note that the front-end delay was still equal to at least 1 day, so that no participant could choose to receive the gift payment directly during the interview. 
of the three scenarios.

Finally, the first round included choices for a short-duration offer, in which participants could receive weekly payments over the next two weeks (and thus over only one two-week period), versus a long-duration offer, in which they could receive weekly payments in each of the next four two-week periods. Participants made these choices for each of the three price scenarios. Hence, for every participant, we have in total $4 \times 3$ allocations for the longduration offer, and $1 \times 3$ allocations for the short-duration offer, yielding 15 allocations in total. At the end of the first-round interview, we randomly selected a price, and either the short-duration or the long-duration offer. The allocations for this randomly selected scenario were implemented by Metkei during the period between the first and the second round 11

We started with this more complex design in the first round (compared with the secondround design) with the aim of assessing under which parameters farmers are interested in weekly payments. In addition, we aimed to create exogenous variation in the take-up of weekly payments in order to be able to assess the impacts of weekly payments on the quantity of milk that farmers deliver to the cooperative. However, as we will show the demand for weekly payments was very limited, irrespective of the milk price for early payments or the duration of the offer. We therefore simplified the second-round design to include the allocation of a gift in order to assess whether the strong preference for deferred payments generalizes to other, less regular, income types.

\footnotetext{
${ }^{11}$ Appendix Table A1 describes all income allocation options presented to the participants during the first and second rounds. In the first round, we implemented every choice with some probability in order to incentivize participants to state their preferences truthfully. We randomly assigned half of the participants to the first scenario, in which they made choices for each of the next four two-week periods (an eight-week offer), and the remaining half to the two-week scenario. For the prices, we assigned 98 percent of the participants to the same-price scenario and 1 percent each to the higher- and lower-price scenarios.
} 


\subsection{Procedures}

The study was carefully designed to ensure that participants were well informed about the decisions they were asked to make and that they trusted Metkei to make the payments according to their allocation. Table 2 provides a study timeline. In November-December 2015, prior to the intervention, the study team, together with Metkei staff, organized sensitization sessions to inform participants about the upcoming choices, to raise awareness, and to build trust. The team further distributed flyers at the milk collection points and via the transporters, followed by the first-round interview. In addition to the first-round

milk payment allocations described above, we collected data on demographic and socioeconomic characteristics as well as milk production, practices, and spending. We also elicited incentivized measures of risk aversion using a Binswanger lottery. The study coordinator paid earnings from this lottery via mobile money on the first Friday after the interview.

In February-March 2016, we visited the same participants for the second interview. In that interview, participants were presented with the main (and simplified) allocation tasks. Thus, they allocated two types of income -the payments for milk delivered in the subsequent four weeks and the gift for participating in the survey- between an earlier and a later payment date. Participants made separate decisions regarding milk payments for each of the subsequent four weeks. In both rounds, all choices were recorded on a sheet of paper, which the participants kept as a reminder of what they had chosen and earned during the survey period. Both allocation tasks were preceded with detailed instructions and test questions to make sure participants had understood the setup, including the fact that there would be no additional cost for receiving the weekly payments.

We elicited the gift allocation after participants had allocated their milk payments and after they had answered a number of survey questions. The KSh 250 was introduced as a reward for participating in the survey, but only at the end of the interview. Hence, the 
gift cannot have influenced the allocations of milk payments.

During the eight and four weeks after the first-round and second-round interviews, respectively, participants received their weekly payments if they had opted to receive one. Specifically, we retrieved the quantity of milk delivered since the previous Friday from the administrative database on Thursday evenings. We matched these deliveries with participants' selected milk payment allocations, calculated the weekly payment to be made, and sent a list of payments to be made to the person responsible for payouts at Metkei. She made the payments on Friday mornings. The study coordinator directly sent gift payments via mobile money on the assigned dates.

\section{Results}

\subsection{Intertemporal Allocations of Milk and Gift Payments}

Participants allocated both their milk payments and a gift between an earlier and a later payment date. The most straightforward way of comparing the two types of income allocations is to summarize choices in terms of the share of the total payment under consideration (the "budget") that is allocated to the early payment date. In a few cases, farmers allocate more than 50 percent of their expected milk production to the early payment date, although their budget was 50 percent of expected milk production. For ease of presentation, their share of income allocated to the early payment date is censored to 1, but results are robust to using the noncensored share. For the gift, the budget to be allocated between the two dates is KSh 250 .

Figure 2 presents the distribution of intertemporal allocations in the second round separately for all four milk income allocations (in gray) and for the gift income allocation (in white). It shows a stark difference between the allocations of milk payments and of the gift. When allocating milk income, most participants chose to defer the receipt of 
the entire milk payment to the regular, later payment date, allocating none to the early payment date. In contrast, a large majority of participants chose to receive the entire gift on the early payment date. Only very few allocations fell in the interior of the distribution, where some part of the budget was allocated to both payment dates.

Figure 2 treats every choice as one observation, meaning that for every participant, the figure includes four milk payment allocations: one for each week in the four-week period following the interview. Table 3 instead summarizes the choices at the participant level, showing that 93 percent of all participants selected no weekly milk payment, whereas only 7 percent chose not to receive any gift income "early". In contrast, less than 1 percent chose to receive the maximum possible milk payment early in every week as opposed to 83 percent who chose to receive the entire gift on the early payment date. Conditional on choosing to receive payments on both the early and the later date (6.5 percent for allocations of milk payments and 10.4 percent for allocations of the gift), participants split the budget equally between the two dates, independent of the income type. Finally, the correlation between both choices is very small and statistically insignificant. Participants deferring their milk payments are not more likely to also defer their gift.

Appendix Table A3 assesses the robustness of the design of the two experimental tasks. Columns (1)-(4) focus on second-round allocations only. Columns (5) and (6) include both first-round and second-round allocations. Odd-numbered columns display the results of regressing the share of a budget allocated to the early payment date on a binary variable indicating milk payments and other controls as shown in the table. Even-numbered columns estimate the same model including respondent fixed effects 12

Columns (3)-(4) test to what extent differences in front-end delays, or a magnitude

\footnotetext{
${ }^{12}$ Because respondents made intertemporal allocations of both milk payments and the gift, the main variable of interest, "milk payment," is balanced across participants, and we do not need to control for respondent characteristics such as age, gender, or relationship to the household head. In order to improve precision, the even-numbered columns nonetheless control for respondent fixed effects.
} 
effect (Frederick, Loewenstein and O'Donoghue, 2002, Andersen et al., 2013), can account for the stark differences between the intertermporal allocations of milk payments and the gift. Columns (5) and (6) add first-round allocations of milk payments, for which we have variation in the milk price for weekly payments (that is, a return on waiting) and in the duration of the offer (that is, whether participants made an allocation only once or for several periods). Treating every choice as one observation, the table regresses the share allocated to the early date on a binary indicator for allocations of milk payments (using gift allocations as a base), controlling for other choice attributes. Standard errors are clustered by participant. The low demand for early milk payments cannot be explained by front-end delays, the delay between the two payment dates, or the magnitude of the experimental stakes. Demand increased when participants received KSh 2 extra per kilogram of milk paid early, but even then most participants rejected the early payment option. 13

One possible concern is that the available "milk budget" can differ from the marketable milk budget, either because households consume a significant share of the milk or because they plan on selling their milk outside Metkei, or both. because we define the milk budget as 50 percent of expected production instead of the expected quantity of milk sold to Metkei, we may overstate the milk budget and hence understate the share of milk income that is allocated to early payments. Therefore, Appendix Table A3 also controls for the self-reported share of milk production consumed on the day prior to the interview. This variable is unrelated to the share of income allocated to the early payment date. Appendix Table A5 finds very similar results using the actual quantity of milk that a participant delivers to the cooperative (measured by the cooperative in preparation for making the

\footnotetext{
${ }^{13}$ Many participants chose a corner allocation, that is, to allocate their entire budget to either the early or the later payment date but not to both. We therefore also estimate a logit model for binary dependent variables in Appendix Table A4 coding choices as binary variables. In Columns (1)-(3), the dependent variable takes a value of 1 if at least part of the budget is allocated to the early payment date. In Columns (4)-(6), it takes a value of 1 if the entire budget is allocated to the early date. The estimated difference between the two allocation types remains large and significant in all specifications.
} 
monthly milk payments) in calculating the share of income allocated to the early payment date.

In summary, participants allocated regular payments very differently than the way they allocated an irregular gift. Most of them prefered to receive the entire gift on the early payment date but allocated their entire milk payment to the later date. The allocations of the gift conform with standard economic predictions for discounters of future income, for whom it is desirable to receive the income as soon as possible 14 However, they conform only for the irregular windfall; the vast majority of participants deferred the more regular milk payments. We cannot attribute this finding to differences in front-end delays, the magnitude the of experimental stakes, or our definition of the available milk budget. Further, the demand for early payments is relatively insensitive to changing the return on deferred payments.

\subsection{Reasons for Allocating Milk Payments to the Later Date}

Table 4 presents self-reported reasons for never selecting the weekly milk payments. Among participants who never selected a weekly payment in the second round, nearly all -95 percent- indicated a preference for setting their milk payments aside for lump-sum expenditures or emergencies, instead of facing the temptation to spend the money on something else. This is the most important reason for 78 percent of the participants. Participants thereby express a demand for commitment savings (Ashraf, Karlan and Yin, 2006, Bryan, Karlan and Nelson, 2010). Alternative explanations, in particular the high transaction costs of receiving an extra payment ("amount too small"), having to share early payments with others, and worries that the early payments could harm the cooperative, are indicated as a reason by some participants, but rarely the main reason.

\footnotetext{
${ }^{14}$ Given that we did not measure whether participants spent their gift immediately or set (some of) the payment aside, we do not claim to measure discount rates over consumption.
} 
A lack of trust in receiving the early payments is never mentioned as a reason for rejecting the early payments, let alone as the main reason for doing so. The study was indeed carefully designed to that ensure participants trusted Metkei to make the early payment. Metkei made both milk payments, not only the regular (later) payments; enjoyed high trust from participants; and endorsed the study to the our participants ${ }^{15}$ Further, the few participants who opted to receive early payments in the first round had received these payments, improving their trust in the implementation.

We also took care to limit transaction costs associated with receiving early milk payments. Because weekly payments may be perceived as necessitating additional travel to the collection point, we offered participants the option to receive their weekly payments directly via mobile money at no extra charge 16 Despite that option, participants did not opt for weekly payments even in the higher-price scenario, which provided some compensation for potential withdrawal fees (see Appendix Table A3). Moreover, self-deliverers who lived near the collection points could pick up their weekly payment at no additional cost when delivering their milk, but even they were not significantly more likely to select weekly payments (see Table 5, which estimates the share of income allocated to the early date, disaggregated by means of delivery: via a transporter or self-delivery).

A few participants (9.4 percent) expressed a worry that the early payments might harm the cooperative and hence future prices. However, for only 0.3 percent was this the main reason for not taking early payments. Participants' distrust, or a preference to comply with cooperative rules, may have been stronger in the first round, when they had not yet seen the cooperative committing to early payments. However, controlling for expected milk production, first-round demand for early milk payments was 3.8 percentage

\footnotetext{
${ }^{15}$ During the first-round survey, the Metkei cooperative received an average of 8.2 on a 10-point scale with 1 as the lowest and 10 the highest possible trust. The main alternative buyer for participants' milk received a 5.0 on average.

${ }^{16}$ About 40 percent of the participants opting for weekly payments chose to collect them in cash at the collection point, and the rest chose to be paid via M-Pesa.
} 
points higher than that in the second round (see Appendix Table A3. These findings provide further indication that distrust, a preference for complying with cooperative rules, and transaction costs do not explain the strong demand for deferred payments, thereby corroborating farmers' self-reported reasons for rejecting early payments.

\subsection{Reasons for Allocating the Gift to the Early Date}

This section discusses why farmers allocated their gift to the early payment date, despite their strong preference for deferred payments when deciding about dairy income. We will first rule out the hypothesis that these differences are due to differences in trust or transaction costs, followed by a discussion of other behavioral mechanisms that are related to the regularity of milk payments and the irregularity of the gift. This discussion will include mental accounting, reference dependence, habit formation, and the ability to control or hide milk payments versus the gift when being paid early.

A first concern could be that participants may prefer being paid on the early date in order to receive a payment only once. Because participants received a payment of KSh 65 (about US\$0.65) at both the early and the later date, regardless of their allocation of the KSh 250 budget over both dates, transaction costs were equal for the two payment dates, and there was no penalty for being paid on both dates. If motives related to transaction costs rather than discounting were driving the gift allocations, participants should have been indifferent between allocating all income to either the early or the later date. Hence, allocations to the later payment date should have been equally as likely as allocations to the early payment date. Nonetheless, only 6.8 percent chose to receive the entire gift on the later date (see Table 3), suggesting that payments on the later date were discounted.

Another concern could be that participants trusted the experimenter to pay the gift only on the earlier date, not on the later date. This is a concern mainly in experiments that 
make the earlier payment during the interview itself, rendering it guaranteed, while the later payment involves the experiment coming back at a later date, which is not guaranteed. In our experiment, this is not as much of a concern because the sooner payment was made a few days after the interview (Chabris, Laibson and Schuldt, 2010) ${ }^{17}$ Moreover, 90 percent of participants had received a payout from a Binswanger-type lottery after the first-round interview, thus having seen the experimenters keep their promises ${ }^{18}$

\subsection{Mechanisms Related to the Regularity of Milk Payments}

Although the milk payments are a regular type of income, the windfall (gift) is an irregular income type, that is, a one-time compensation for participating in the survey. This section will discuss four mechanisms to explain the non-fungibility of irregular versus regular income in intertemporal choice: mental accounting, habit formation, reference-dependent preferences, and income visibility.

First, regularity allows farmers to engage in income accounting, a form of mental accounting (Thaler, 1999). Farmers may assign milk income from the cooperative to a mental account that is designated to saving for bulky expenditures such as school fees, agricultural investments, medical expenditures, and other emergencies. In contrast, revenues from selling milk or other produce on local markets are assigned to a different mental account, one used for small purchases. The offer of more frequent payments of milk revenues is then perceived as an offer to use funds from the "savings account" for liquidity purposes, and it is therefore rejected, even when a higher price is offered. Conversely, the gift payment is not assigned to a mental account subject to a specific spending rule. Standard time

\footnotetext{
${ }^{17}$ It could still be that trust depends on the time horizon, for instance if the late payment date is after the end of the main study period and participants worry that they then have less clout to enforce the gift payment. However, both proposed gift payment dates were within the four-week period for which the participants made milk payment choices, and farmers knew how to contact us if they did not receive an expected payment.

${ }^{18}$ These payoffs ranged between KSh 125 and KSh 950 (about $\$ 1.25$ to $\$ 9.50$ ) and were sent via M-Pesa, in the same way we sent the second-round gift.
} 
preferences then lead to a preference for the early payment.

Survey data support the view that farmers engage in income accounting. In the second round, we asked farmers how they were planning to spend the income from the milk sold yesterday. Appendix Table A6 shows that only 29 percent of participants planned to spend their milk payment from the cooperative on food or other daily expenditures, but 91 percent planned to use milk payments from other buyers for those purposes. Conversely, more than 60 percent of participants planned to spend the cooperative milk payment on bulky expenditures such as school fees and agricultural inputs, whereas few participants planned to spend payments from other buyers for these purposes. This difference becomes even larger when we restrict the sample to participants who sold milk to both the cooperative and another buyer on the day prior to the interview. Under this restriction, the same participants assign milk income from the two types of buyers to very different uses.

To explore these relationships further, Table 6 estimates the allocation gap separately for different types of participants. Odd-numbered columns include only second-round allocations. Even-numbered columns also include first-round allocations. Columns (1) and (2) distinguish between those who are planning to use the income from milk delivered to the cooperative for lump-sum expenditures (the reference category) versus food and other small purchases. The latter are more likely to choose weekly payments. The same applies to participants who deliver afternoon milk to Metkei, which is typically used for smaller and more frequent purchases such as food (see Appendix Table A6). These findings, along with the stated income uses, suggest that farmers treat their milk income differently depending on whether it is from the cooperative or another buyer, whether it is morning or afternoon milk, and whether it is commonly used to pay for daily expenditures. Hence, findings support the view that participants engage in income accounting.

Second, regularity may matter because of reference dependence. In theory, when ref- 
erence points are based on expectations held before consumption, there is an asymmetric tendency to consume windfall gains (Kőszegi and Rabin, 2009), for instance an irregular gift for participating in a survey. Because the farmers were already expecting milk payments on the 11th of the next month, a reallocation would result in lower future consumption than expected, creating a utility loss in the future. A loss-averse participant will weigh this utility loss more heavily than the corresponding utility gain from consuming more than expected in the present, a judgment that induces the participant to maintain the status quo and reject the weekly milk payments. This response is entirely consistent with farmers' self-reported aspiration to save their money for bulky lump-sum expenditures.

A third channel through which regularity may matter is habit formation or status quo bias: habit formation in this context means that the utility from the current payment profile depends on the past payment profile (compare Duesenberry (1952)). Simply because milk payments were deferred in the past, farmers may prefer to defer them also in the future. This explanation is closely related to the idea that the farmers may exhibit a status quo bias driven by loss aversion (Kahneman, Knetsch and Thaler, 1991). According to this view, the only reason farmers prefer to defer milk payments from the cooperatives that they are used to receiving them this way. In contrast, there is no habit or status quo for the receipt of gift payments, which means that standard time preferences prevail. Note, however, that the self-reported reasons for rejecting weekly payments suggest that farmers value deferred milk payments because they help with saving.

Fourth, regularity may matter due to the visibility of such income to others, for instance one's husband, who may be tempted to spend the money. A dairy farmer may not want to get some of the milk money paid at the end of the week out of concern that her husband may take it and spend it; by deferring the payment, she will not have to worry about her husband spending the money because it is locked away with the cooperative. Conversely, 
she can hide irregular income, such as the experimental gift, and keep it with her for an emergency, because her husband will not know she received the money.

In our context, we would expect this effect to be strongest for women. Columns (5) and (6) of Table 6 therefore assess whether the choice gap is larger for female than for male dairy farmers. Contrary to expectation, though, women are not significantly less likely to select weekly payments than men. Similarly, we would expect the gap to be smaller among self-identified household heads. However, Columns (7) and (8) do not find a significantly higher demand for weekly payments among this group $\sqrt{19}$ Finally, although 36.7 percent of participants indicated that having to share weekly payments with family or friends was $a$ reason for rejecting weekly payments, it was the main reason for only 3.6 percent.

These findings suggest that habit formation and intrahousehold bargaining motives alone cannot account for the differences in the intertemporal allocations. To distinguish between mental accounting and reference-dependent time preferences, a challenge is that milk income is a regular source of income in two distinct ways. First, in contrast to the gift, the milk payment is both a familiar source of income-deemed relevant for mental accounting-and anticipated-relevant for theories of reference-dependent decision making. One way of distinguishing which of these theories explains our results would be to study whether farmers' milk payment allocations react to unanticipated changes in milk payments. A low elasticity of allocations with respect to changes in the milk price, such as the one we find for the first-round allocations (see Table A3), suggests that expectations-based reference points may not be relevant in our setting, although elasticity may also be low because these changes in milk price do not induce substantial variation in prospective milk income 20

\footnotetext{
${ }^{19}$ Also women who were not household heads were not significantly less likely to select weekly payments (results available upon request).

${ }^{20}$ Casaburi and Macchiavello 2016) offered a larger increase in the daily price of milk (16 percent, as compared with our 7 percent increase in the weekly price) and also found their offer rejected by a large majority of farmers.
} 
We were surprised by the high demand for deferred milk payments, given the high demand ex ante for costly advances. What distinguished weekly payments from the more popular advances in the eyes of the participants is the farmer's lack of flexibility. Additional analysis finds that 16 percent of second-round participants who rejected weekly payments expected to take advances within the next four weeks. More than 80 percent of them said they preferred this way of receiving liquidity because the decision to take an advance could be made spontaneously, or because the advance payment could be received on any day of the week. These explanations suggest that the optimal informal contract in settings such as ours should take into account the need for both ex ante commitment and ex post flexibility.

In summary, for participants who plan to use their milk income for small purchases, demand for deferred payments is still high, but lower than for those who plan to use their milk income for lump-sum expenditures. This finding is consistent with the hypothesis that dairy farmers apply different mental accounts to different sources of income. Money from milk delivered to the cooperative is saved for lump-sum expenditures, but that from milk sold to buyers in the local market, who pay immediately, as well as irregular windfalls, are spent on smaller but more frequent expenditures. Combined, the income allocations and survey evidence suggest that mental accounting or reference dependence, in conjunction with deferred milk payments, helping savings-constrained farmers to meet their savings goals, is most likely to account for our findings.

\section{Conclusion}

We find that dairy farmers of a Kenyan cooperative preferred to defer their milk payments but chose to receive an experimental gift at the earlier of two possible payment dates. Potential confounding factors such as differences in stakes, front-end delays, trust, and 
transaction costs do not seem to account for this discrepancy. Our results are consistent with both the experimental literature, which generally finds a preference for early over late receipts of windfalls (compare Frederick, Loewenstein and O'Donoghue, 2002), and with observational studies, which reveal lower discount rates for more regular income types and a demand for commitment savings or deferred payments Ashraf, Karlan and Yin, 2006, Bryan, Karlan and Nelson, 2010; Casaburi and Macchiavello, 2016).

Our findings are not an artifact of the cooperative we chose to work with. In a comparable study in a different part of Kenya, 83 of 96 dairy farmers (86 percent) declined the offer to be paid for their milk upon delivery (Casaburi and Macchiavello, 2016), mirroring our 93 percent of second-round participants who never chose weekly payments. Moreover, 73 percent of those farmers referred to self-control problems or the need to achieve savings targets as motivating their decisions, comparable to our 78 percent. In both studies, farmers appeared to use the deferred milk payments as a commitment device to overcome their limited access to sound savings instruments. We were however, unable to replicate this result for allocations of an experimental gift, supporting the conclusion by Cohen et al. (2016) that intertemporal choice over regular income does not always reflect domaingeneral time preferences. Conversely, time preferences elicited using experimenter money are not necessarily predictive of participants' intertemporal allocation decisions for more regular sources of income.

We propose mental accounting, reference-dependent intertemporal choice, habit formation, and others' ability to request or spend the money as four mechanisms through which the regularity of the income may matter. Although our experiment does not allow us to distinguish clearly between these mechanisms, survey evidence and heterogeneity in milk income allocations suggest that farmers assign milk income from the cooperative, but not gift income, to a mental savings account for bulky expenditures. An area for future 
research would be to disentangle whether non-fungibility in intertemporal choice is created by mental accounting or reference dependence, and whether in other settings it is due to other mechanisms than those highlighted in the present study. Another open question is whether farmers with a stronger demand for commitment savings select into informal contracts that defer payments, or whether their demand for commitment savings develops once they become used to such payments.

These findings have implications for the design of informal contracts between farmers and aggregators in agricultural value chains such as cooperatives, producer groups and contract farming arrangements. Farmers may value deferred payments from trustworthy institutions. In such contexts, aggregators should abstain from making more frequent payments the default, irrespective of whether discount rates elicited using experimenter money would suggest otherwise. We do, however, observe a strong demand for advance payments along with the low demand for early and more frequent payments. Instead of paying early, aggregators may want to provide more flexibility in the form of advance payments. Aligning the conditions of informal contracts with farmers' preference for when to be paid could help improve farmers' loyalty to the contracts, thereby helping aggregators operate more effectively and realize economies of scale, an important consideration for increasing agricultural productivity (Muriuki, 2011).

These results, however, also raise the question of how increased financial inclusion will affect farmers' loyalty toward their aggregators. If producers adherence to informal contracts with institutions such as cooperatives, producer groups, and contract farming programs hinges on their trustworthiness to defer payments (and act as savings institutions), then increased access to sound savings instruments outside the agricultural value chain could potentially reduce this loyalty. An important topic for future research is whether there is indeed such an undesirable side effect of increased financial inclusion. 
Finally, our results also suggest that intertemporal allocation rules are income-type specific, and that irregular income types are more susceptible to being spent immediately. To the extent that mental accounting or habit formation matters, policy makers interested in "nudging" savings or consumption decisions may want to target types of income that are currently assigned to a similar mental account, or at least those for which no conflicting mental accounting rule exists. Further, if reference dependence matters, our findings suggest that in order for new types of income, for instance cash transfers, to improve savings, they should be introduced as a regular income source as opposed to a one-time windfall.

\section{References}

Andersen, S., G.W. Harrison, M.I. Lau, and E.E. Rutström. 2008. "Eliciting Risk and Time Preferences." Econometrica, 76(3): 583-618.

Andersen, S., G.W. Harrison, M.I. Lau, and E.E. Rutstrőm. 2013. "Discounting Behaviour and the Magnitude Effect: Evidence from a Field Experiment in Denmark." Economica, 80(320): 670-697.

Ashraf, N., D. Karlan, and W. Yin. 2006. "Tying Odysseus to the Mast: Evidence from a Commitment Savings Product in the Philippines." Quarterly Journal of Economics, 121(2): 635-672.

Bowman, D., D. Minehart, and M. Rabin. 1999. "Loss Aversion in a ConsumptionSavings Model." Journal of Economic Behavior \& Organization, 38(2): 155-178.

Bryan, G., D. Karlan, and S. Nelson. 2010. "Commitment Devices." Annual Review of Economics, 2(1): 671-698.

Camerer, C.F., J.D. Cohen, E. Fehr, P.W. Glimcher, and D. Laibson. 2015. "Intertemporal Choice and Self-regulation." In The Handbook of Experimental Economics, Vol. 2, ed. J.H. Kagel and A.E. Roth, Chapter 3, 177-183. Princeton: Princeton University Press.

Casaburi, L., and R. Macchiavello. 2016. "Firm and Market Response to Saving Constraints: Evidence from the Kenyan Dairy Industry." CEPR Discussion Paper No. DP10952. Washington, DC: Center for Economic and Policy Research

Chabris, C.F, D.I Laibson, and J.P Schuldt. 2010. "Intertemporal Choice." In $B e$ havioural and Experimental Economics, 168-177. New York: Springer. 
Chuang, Y., and L. Schechter. 2015. "Stability of Experimental and Survey Measures of Risk, Time, and Social Preferences: A Review and Some New Results." Journal of Development Economics, 117: 151-170.

Cohen, J.D, K.M. Ericson, D. Laibson, and J.M. White. 2016. "Measuring Time Preferences." NBER Working Paper No. 22455. Cambridge, MA, US: NBER.

Dean, M., and A. Sautmann. 2016. "Credit Constraints and the Measurement of Time Preferences." Department of Economics Working Paper. Providence, RI, US: Brown University.

Duesenberry, J. 1952. Income, Saving, and the Theory of Consumer Behavior. Camridge, MA, US: Harvard University Press.

Duflo, E., and C. Udry. 2004. "Intrahousehold Resource Allocation in Cote dIvoire: Social Norms, Separate Accounts and Consumption Choices." NBER Working Paper No. 10498. Cambridge, MA, US: NBER.

Dupas, P., J. Robinson, and S. Saavedra. 2016. "The Daily Grind: Cash Needs, Labor Supply and Self-Control." Working paper. Cambridge, MA, US: NBER.

Frederick, S., G. Loewenstein, and T. O'Donoghue. 2002. "Time Discounting and Time Preference: A Critical Review." Journal of Economic Literature, 40(2): 351-401.

Geng, X., B. Kramer, and W. Janssens. 2017. "Liquid Milk: Cash Constraints and Day-to-Day Intertemporal Choice in Financial Diaries." IFPRI Discussion Paper 01602. Washington, DC: International Food Policy Research Institute.

Halevy, Y. 2015. "Time Consistency: Stationarity and Time invariance." Econometrica, 83(1): 335-352.

Harrison, G.W., and J. List. 2004. "Field Experiments." Journal of Economic Literature, 42(2): 1009-1055.

Janssens, W., B. Kramer, and L. Swart. 2017. "Be Patient when Measuring Hyperbolic Discounting: Stationarity, Time Consistency and Time Invariance in a Field Experiment." Journal of Development Economics, 126(May): 77-90.

Kahneman, D., J.L. Knetsch, and R.H. Thaler. 1991. "Anomalies: The Endowment Effect, Loss Aversion, and Status Quo Bias." Journal of Economic Perspectives, 5(1): 193-206.

Kooreman, P. 2000. "The Labeling Effect of a Child Benefit System." American Economic Review, 90(3): 571-583.

K"oszegi, B., and M. Rabin. 2009. "Reference-dependent Consumption plans." The American Economic Review, 99(3): 909-936. 
Kramer, B. 2016. "When Expectations Become Aspirations: Reference-dependent Preferences and Liquidity Constraints." Economic Theory, 61(4): 685-721.

Meier, S., and C.D. Sprenger. 2015. "Temporal Stability of Time Preferences." The Review of Economics and Statistics, 97(2): 273-286.

Minot, N., and B. Sawyer. 2014. "Contract Farming in Developing Countries: Review of the Evidence." Prepared for the Investment Climate Unit of the International Finance Corporation as a longer version of the IFC Viewpoints policy note on the same topic.

Muriuki, H.G. 2011. "Dairy Development in Kenya." Rome: Food and Agriculutural Organization of the United Nations.

Reardon, T., C.B. Barrett, J.A Berdegué, and J.F.M. Swinnen. 2009. "Agrifood Industry Transformation and Small Farmers in Developing Countries." World Development, 37(11): 1717-1727.

Thaler, R.H. 1990. "Anomalies: Saving, Fungibility, and Mental Accounts." Journal of Economic Perspectives, 4(1): 193-205.

Thaler, R.H. 1999. "Mental Accounting Matters." Journal of Behavioral Decision Making, 12(3): 183-206.

Ubfal, D. 2016. "How General are Time Preferences? Eliciting Good-specific Discount Rates." Journal of Development Economics, 118(C): 150-170.

Vargas Hill, R., E. Maruyama, M. Olapade, and M. Frölich. 2015. "Strengthening Producer Organizations to Increase Market Access of Smallholder Farmers in Uganda." Working paper. Washington, DC: World Bank.

Villa, K.M., C.B. Barrett, and D.R. Just. 2011. "Differential Nutritional Responses across Various Income Sources Among East African Pastoralists: Intrahousehold Effects, Missing Markets and Mental Accounting." Journal of African Economies, 20(2): 341375 . 
Figure 1: Timeline for experimental tasks

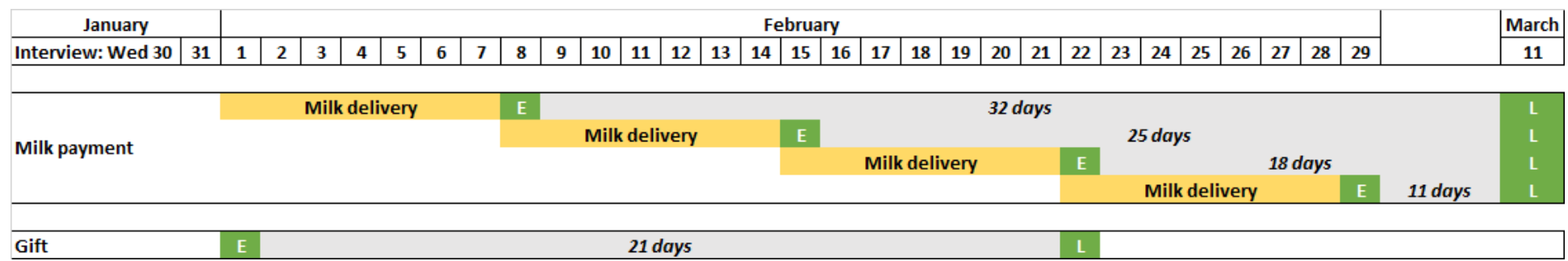

(a) Example for an interview on Wednesday January 30

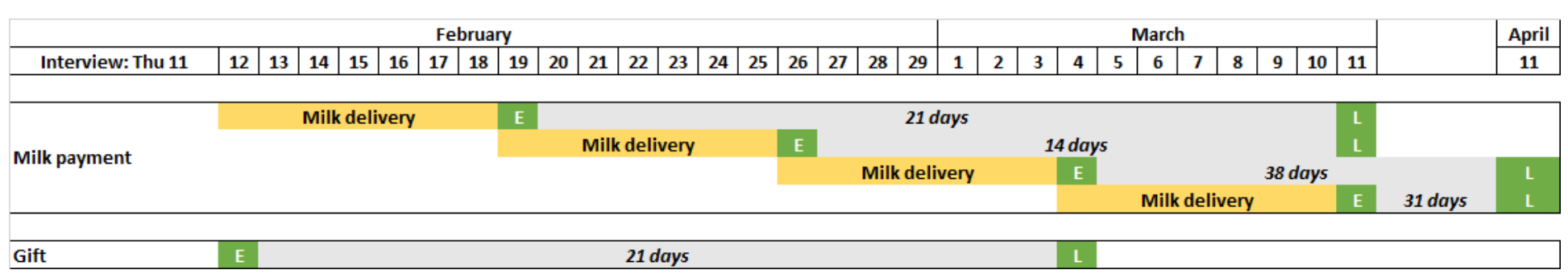

(b) Example for an interview on Thursday February 11

Note On the interview day, the participant allocates payments between an early ('E') and late (' $\mathrm{L}$ ') payment date. Text in italics indicates the number of days between the early and late payment date. Participants make allocations for in total four milk delivery periods (indicated in yellow) and a gift. Regarding milk payments, the median delay between the two dates is 21 days, with front-end delays (number of days between the interview and the early payment) ranging between 7 and 35 days. Regarding the gift, the delay between the two dates is always 21 days, with a front-end delay between 1 and 7 days. When calculating days between early and late milk payments, we assign weeks according to the majority of days. However, in practice, the later payment date for a given day is the 11th of the next month, even if the remainder of the week falls in the next month so that the effective deferred payment date is one month later. 
Figure 2: Share of payment allocated to the early date

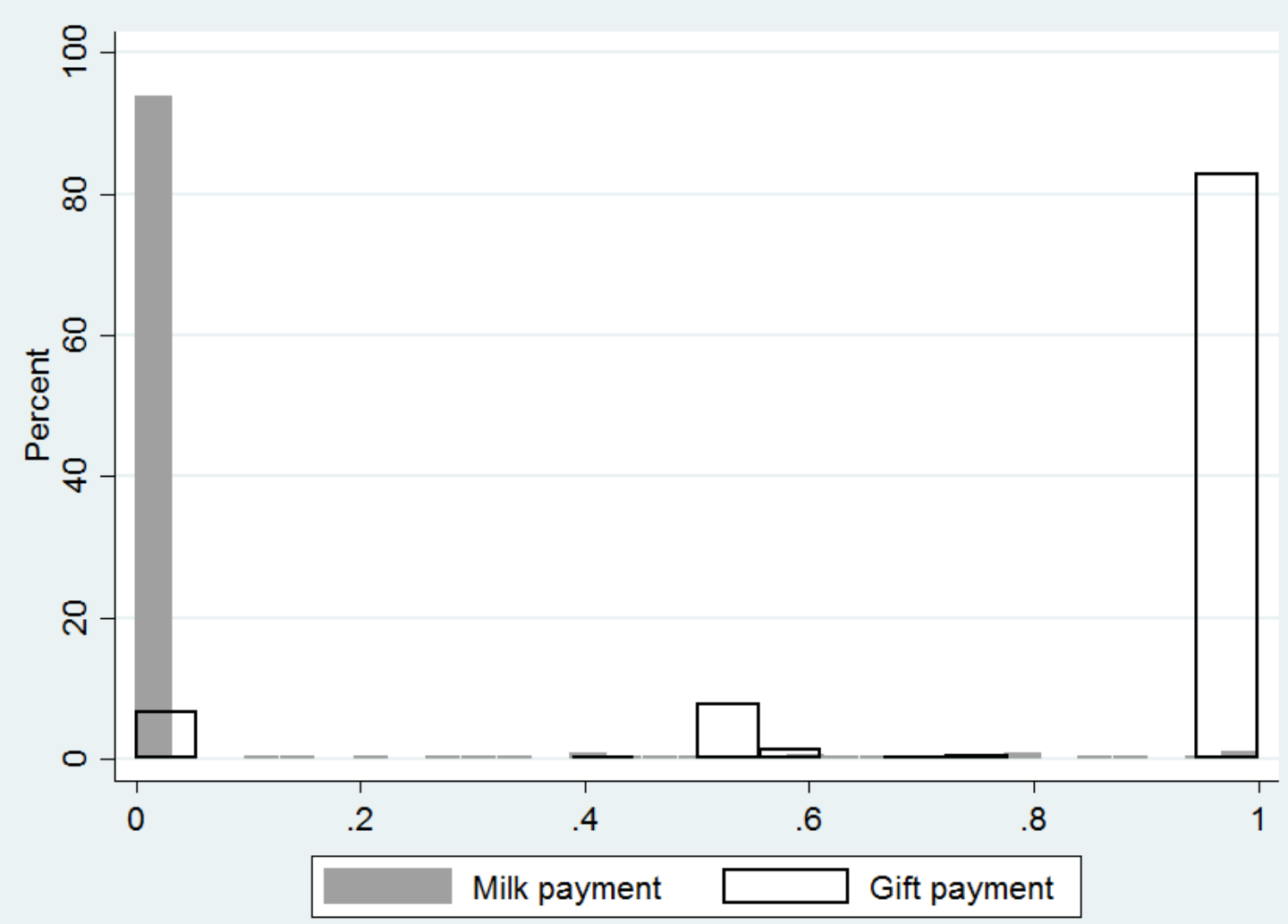

Note Histogram of second-round income allocations between an early payment date and a late payment date, treating every choice as one observation $(N=1,770)$. The maximum amount of milk income that a respondent could allocate to the early date in a given week is calculated as $50 \%$ of the respondent's expected milk production for that week, unless the respondent is among the few who delivered afternoon milk only to Metkei, in which case we calculate the budget for milk income allocations as $100 \%$ of the respondent's expected milk production for that week. 
Table 1: Respondent characteristics

\begin{tabular}{|c|c|c|c|c|c|}
\hline \multirow[b]{2}{*}{ Panel A: Demographics } & \multicolumn{2}{|c|}{ All respondents } & \multicolumn{2}{|c|}{ Present both rounds } & \multirow{2}{*}{$\begin{array}{c}\text { p-value } \Delta \\
(5)\end{array}$} \\
\hline & $\begin{array}{c}\text { Mean } \\
(1)\end{array}$ & $\begin{array}{l}S d . \\
(2)\end{array}$ & $\begin{array}{c}\text { Mean } \\
(3)\end{array}$ & $\begin{array}{l}S d . \\
(4)\end{array}$ & \\
\hline Age & 45.18 & 13.57 & 45.78 & 13.52 & 0.42 \\
\hline Years of experience in dairy farming & 13.82 & 11.75 & 14.02 & 11.80 & 0.76 \\
\hline Female $(\%)$ & 46.21 & & 41.59 & & $0.09^{\dagger}$ \\
\hline Primary schooling completed (\%) & 79.34 & & 79.20 & & 0.95 \\
\hline Secondary schooling completed (\%) & 40.82 & & 40.06 & & 0.78 \\
\hline Dairy farming main income source (\%) & 81.38 & & 83.49 & & 0.31 \\
\hline \multicolumn{6}{|l|}{ Panel B: First round } \\
\hline Delivers PM milk to Metkei & 17.66 & & 16.51 & & 0.58 \\
\hline Number of currently lactating cows & 2.52 & 1.82 & 2.53 & 1.81 & 0.94 \\
\hline Kg milk produced yesterday (survey) & 12.77 & 9.80 & 13.02 & 9.64 & 0.64 \\
\hline - Sold to someone else (\%) & 4.68 & 10.18 & 5.00 & 10.59 & 0.59 \\
\hline - Consumed (\%) & 47.64 & 24.28 & 45.67 & 23.19 & 0.13 \\
\hline - Survey: Delivered to co-op (\%) & 45.76 & 24.54 & 47.55 & 23.76 & 0.18 \\
\hline - Admin. data: Delivered to co-op (\%) & 36.27 & 30.51 & 37.57 & 30.55 & 0.44 \\
\hline Net milk price cooperative (KSh) & 33.72 & 2.46 & 33.64 & 2.47 & 0.60 \\
\hline Net milk price other buyer (KSh) & 31.97 & 5.27 & 31.60 & 4.45 & 0.40 \\
\hline \multicolumn{6}{|l|}{ Panel C: Second round } \\
\hline Delivers PM milk to Metkei & 13.24 & & 9.79 & & $0.04^{*}$ \\
\hline Number of currently lactating cows & 2.66 & 1.79 & 2.60 & 1.79 & 0.53 \\
\hline Kg milk produced yesterday (survey) & 13.10 & 10.16 & 13.16 & 10.17 & 0.90 \\
\hline - Sold to someone else (\%) & 5.39 & 11.64 & 4.35 & 9.57 & $0.05^{*}$ \\
\hline - Consumed (\%) & 38.88 & 20.13 & 38.85 & 19.53 & 0.98 \\
\hline - Survey: Delivered to co-op (\%) & 53.66 & 21.00 & 55.02 & 19.13 & 0.20 \\
\hline - Admin. data: Delivered to co-op (\%) & 42.61 & 28.92 & 43.77 & 28.55 & 0.46 \\
\hline Net milk price cooperative (KSh) & 28.17 & 2.07 & 28.18 & 2.09 & 0.91 \\
\hline Net milk price other buyer (KSh) & 31.37 & 4.15 & 31.52 & 4.34 & 0.74 \\
\hline Respondents first/second/both rounds & $368 / 355$ & & 327 & & \\
\hline
\end{tabular}

Note $\mathrm{KSh}=$ Kenya shilling. Reported milk prices are averages among those respondents who sold either AM or PM milk to the cooperative or another buyer on the day prior to the interview, net of transport costs. Time-invariant characteristics are missing for four respondents due to non-response. ${ }^{\dagger} p<0.10$, $^{*}$ $p<0.05,{ }^{* *} p<0.01$. 
Table 2: Timeline

\begin{tabular}{ccc}
\hline $\begin{array}{c}\text { Sampling } \\
\text { Oct 2015 }\end{array}$ & $\begin{array}{c}\text { Sensitization, first round } \\
\text { Nov - Dec 2015 }\end{array}$ & $\begin{array}{c}\text { Second (main) round } \\
\text { Feb - Mar 2016 }\end{array}$ \\
\hline $\begin{array}{c}\text { Administrative } \\
\text { data handling }\end{array}$ & $\begin{array}{c}\text { Information sessions at } \\
\text { Metkei cooking plants }\end{array}$ & $\begin{array}{c}\text { Interviews with the } \\
\text { same households } \\
\end{array}$ \\
& Distribution of flyers & $\begin{array}{c}\text { Milk payment allocations } \\
\text { for the next 4 weeks }\end{array}$ \\
& $\begin{array}{c}\text { Interviews with milk payment } \\
\text { allocations for 8 next weeks }\end{array}$ & $\begin{array}{c}\text { Allocation of gift for } \\
\text { participating in study }\end{array}$ \\
\hline \hline
\end{tabular}

Table 3: Allocations of milk payments and gifts during the second round

\begin{tabular}{lc}
\hline \hline Milk budget allocations & Value \\
\hline None to early date (\%) & 92.96 \\
Some to early date (\%) & 6.48 \\
Some to early date: Mean \% to early date & 50.54 \\
All to early date (\%) & 0.56 \\
\hline Gift budget allocations & \\
\hline None to early date (\%) & 6.76 \\
Some to early date (\%) & 10.42 \\
Some to early date: Mean \% to early date & 53.78 \\
All to early date (\%) & 82.82 \\
\hline Correlation (Avg. share of milk budget to early date, Share of gift to early date) & -0.05 \\
\hline Respondents & 355 \\
\hline \hline
\end{tabular}

Note Overview of second-round income allocations between an early payment date and a late payment date, treating every respondent as one observation. There are four milk budget allocations and one gift budget allocation per respondent. The maximum amount of milk income that a respondent could allocate to the early date in a given week is calculated as $50 \%$ of the respondent's expected milk production for that week, unless the respondent is among the few who delivered afternoon milk only to Metkei, in which case we calculate the budget for milk income allocations as $100 \%$ of the respondent's expected milk production for that week. 
Table 4: Reasons for rejecting weekly milk payments in round 2

\begin{tabular}{lcc}
\hline \hline & A reason (\%) & Most important reason (\%) \\
\hline Temptation to spend instead of saving & 94.85 & 77.88 \\
Need to share with family/friends & 36.67 & 3.64 \\
Unsure whether enough left for advances & 33.94 & 5.76 \\
Currently no use for the money & 21.21 & 0.91 \\
Amount too small & 21.21 & 3.33 \\
Bad for coop and hence future prices & 9.39 & 0.30 \\
Other & 8.18 & 8.18 \\
\hline Respondents & 330 & 330 \\
\hline \hline
\end{tabular}

Note Responses from the 330 second round respondents who did not select a weekly payment in any of the four weeks. Most common among the 'other' reasons were references to the use of the regular milk payments in the household budget, with school fees being most frequently mentioned.

Table 5: Allocations of the gift versus milk payments by milk delivery mode

\begin{tabular}{lcc}
\hline \hline & \multicolumn{2}{c}{$\begin{array}{c}\text { Dependent variable: } \\
\text { Share of budget allocated to } \\
\text { the early payment date }\end{array}$} \\
\cline { 2 - 3 } & $\begin{array}{c}\text { Round } 2 \text { only } \\
(1)\end{array}$ & $\begin{array}{c}\text { Rounds } 1 \text { and } 2 \\
(2)\end{array}$ \\
\hline Milk payment & $-0.853^{* *}$ & $-0.872^{* *}$ \\
& $(0.027)$ & $(0.029)$ \\
Self-deliverers milk to the collection center & 0.025 & 0.023 \\
& $(0.029)$ & $(0.030)$ \\
$\ldots \times$ milk payment & 0.001 & 0.019 \\
& $(0.034)$ & $(0.033)$ \\
Controls & $\checkmark$ & $\checkmark$ \\
\hline Observations & 1,770 & 7,185 \\
Number of respondents & 355 & 396 \\
R-squared & 0.769 & 0.536 \\
Mean dependent variable & 0.207 & 0.083 \\
\hline \hline
\end{tabular}

Note Estimated using ordinary least squares with standard errors (in parentheses) clustered at the respondent level. Both columns control for budget size, number of days to the early payment, number of days between early and late payments, and self-reported share of milk consumed yesterday. Column (2) also controls for variables that indicate first-round allocations and its interactions with price scenario and offer duration. Participants delivering milk to the collection center themselves could collect the early milk payment from the collection center without incurring additional transaction costs. If transaction costs are the main explanation for the low demand for early milk payments, we would expect the interaction term 'Self-delivers $\times$ Milk payment' to be positive and statistically significant. ${ }^{\dagger} p<0.10,{ }^{*} p<0.05,{ }^{* *} p<0.01$. 
Table 6: Heterogeneity in weekly payment choices

\begin{tabular}{|c|c|c|c|c|c|c|c|c|}
\hline & \multicolumn{8}{|c|}{ Dependent variable: Share of budget allocated to the early payment date } \\
\hline & \multirow{2}{*}{\multicolumn{2}{|c|}{$\begin{array}{c}\text { Subgroup: } \\
\text { Payment for daily } \\
\text { exp.(vs. lump-sum } \\
\begin{array}{c}\mathrm{R} 2 \text { only } \\
(1)\end{array} \\
\begin{array}{c}\left.\exp _{\mathrm{R}}\right) \\
\mathrm{R} 1+\mathrm{R} 2\end{array} \\
\end{array}$}} & \multirow{2}{*}{\multicolumn{2}{|c|}{$\begin{array}{c}\text { Subgroup: } \\
\text { p.m. suppliers } \\
\text { (vs. a.m. suppliers) } \\
\begin{array}{cc}\text { R2 only } \\
(3)\end{array} \\
\begin{array}{c}\text { R } 1+\mathrm{R} 2 \\
(4)\end{array}\end{array}$}} & \multicolumn{2}{|c|}{$\begin{array}{c}\text { Subgroup: } \\
\text { Female suppliers } \\
\text { (vs. male suppliers) }\end{array}$} & \multicolumn{2}{|c|}{$\begin{array}{c}\text { Subgroup: } \\
\text { Household head } \\
\text { (vs. someone else) }\end{array}$} \\
\hline & & & & & $\begin{array}{c}\text { R2 only } \\
(5)\end{array}$ & $\begin{array}{c}\mathrm{R} 1+\mathrm{R} 2 \\
(6)\end{array}$ & $\begin{array}{c}\text { R2 only } \\
(7)\end{array}$ & $\begin{array}{c}\mathrm{R} 1+\mathrm{R} 2 \\
(8)\end{array}$ \\
\hline Milk payment & $\begin{array}{c}-0.876^{* *} \\
(0.021)\end{array}$ & $\begin{array}{c}-0.884^{* *} \\
(0.024)\end{array}$ & $\begin{array}{c}-0.866^{* *} \\
(0.022)\end{array}$ & $\begin{array}{c}0.875^{* *}-0.83 \\
(0.024)\end{array}$ & $\begin{array}{c}7^{* *}-0.849^{*} \\
(0.029)\end{array}$ & $\begin{array}{c}-0.872^{* *}-0 . \\
(0.030)\end{array}$ & $\begin{array}{l}873^{* *} \\
(0.039)\end{array}$ & $(0.043)$ \\
\hline Subgroup & $\begin{array}{l}-0.071^{\dagger} \\
(0.038)\end{array}$ & $\begin{array}{c}-0.072^{\dagger} \\
(0.038)\end{array}$ & $\begin{array}{c}-0.037 \\
(0.038)\end{array}$ & $\begin{array}{l}-0.038 \\
(0.038)\end{array}$ & $\begin{array}{c}0.023 \\
(0.030)\end{array}$ & $\begin{array}{c}0.024 \\
(0.030)\end{array}$ & $\begin{array}{l}-0.037 \\
(0.038)\end{array}$ & $\begin{array}{l}-0.038 \\
(0.038)\end{array}$ \\
\hline$\ldots \times$ milk payment & $\begin{array}{c}0.088^{\dagger} \\
(0.045)\end{array}$ & $\begin{array}{c}0.076^{\dagger} \\
(0.041)\end{array}$ & $\begin{array}{c}0.062 \\
(0.044)\end{array}$ & $\begin{array}{c}0.079^{\dagger} \\
(0.043)\end{array}$ & $\begin{array}{l}-0.034 \\
(0.034)\end{array}$ & $\begin{array}{l}-0.033 \\
(0.033)\end{array}$ & $\begin{array}{c}0.023 \\
(0.042)\end{array}$ & $\begin{array}{c}0.011 \\
(0.044)\end{array}$ \\
\hline Controls & $\checkmark$ & $\checkmark$ & $\checkmark$ & $\checkmark$ & $\checkmark$ & $\checkmark$ & $\checkmark$ & $\checkmark$ \\
\hline Observations & 1,770 & 7,185 & 1,770 & 7,185 & 1,770 & 7,185 & 1,770 & 7,185 \\
\hline Number of resp. & 355 & 396 & 355 & 396 & 355 & 396 & 355 & 396 \\
\hline R-squared Mean & 0.769 & 0.530 & 0.769 & 0.534 & 0.768 & 0.530 & 0.768 & 0.531 \\
\hline dep. var. & 0.207 & 0.083 & 0.207 & 0.083 & 0.207 & 0.083 & 0.207 & 0.083 \\
\hline
\end{tabular}

Note R1 = Round 1. R2 = Round 2. Estimated using ordinary least squares with standard errors (in parentheses) clustered at the participant level. All columns control for budget size, number of days to the early payment, number of days between early and late payments, and selfreported share of milk consumed yesterday. Even-numbered columns also control for variables that indicate first-round allocations and its interactions with price scenario and offer duration. ${ }^{\dagger} p<0.10,{ }^{*} p<0.05,{ }^{* *} p<0.01$. 


\section{A Appendix Tables}

Table A1: Overview of all income allocation choices made by the participants

\begin{tabular}{lcccccc}
\hline \hline Round & $\begin{array}{c}\text { Weeks with } \\
\text { early } \\
\text { (aftepaagrtatyiew) }\end{array}$ & $\begin{array}{c}\text { Front-end } \\
\text { delay } \\
\text { (med. and range) }\end{array}$ & $\begin{array}{c}\text { Days betw. early } \\
\text { and regular } \\
\text { (med. and range) }\end{array}$ & $\begin{array}{c}\text { Income } \\
\text { source }\end{array}$ & $\begin{array}{c}\text { Price } \\
\text { sooner } \\
\text { payment }\end{array}$ & $\begin{array}{c}\text { Offer duration } \\
\text { (max \# weeks w/ } \\
\text { early payment) }\end{array}$ \\
\hline R1 & $1+2$ & $10[8$ to 14$]$ & $24[10$ to 34$]$ & Milk & $+2,+/-0,-2$ & 2 weeks \\
R1 & $1+2$ & $10[8$ to 14$]$ & $24[10$ to 34$]$ & Milk & $+2,+/-0,-2$ & 8 weeks \\
R1 & $3+4$ & $24[22$ to 28$]$ & $24[10$ to 34$]$ & Milk & $+2,+/-0,-2$ & 8 weeks \\
R1 & $5+6$ & $38[36$ to 42$]$ & $20[10$ to 35$]$ & Milk & $+2,+/-0,-2$ & 8 weeks \\
R1 & $7+8$ & $52[50$ to 56$]$ & $27[13$ to 35$]$ & Milk & $+2,+/-0,-2$ & 8 weeks \\
R2 & 1 & $10[8$ to 14$]$ & $21[7$ to 31$]$ & Milk & $+/-0$ & 4 weeks \\
R2 & 2 & $17[15$ to 21$]$ & $21[7$ to 31$]$ & Milk & $+/-0$ & 4 weeks \\
R2 & 3 & $24[22$ to 28$]$ & $17[7$ to 31$]$ & Milk & $+/-0$ & 4 weeks \\
R2 & 4 & $31[29$ to 35$]$ & $17[7$ to 31$]$ & Milk & $+/-0$ & 4 weeks \\
R2 & 1 & $3[1$ to 7$]$ & 21 days & Gift & $+/-0$ & 1 week \\
\hline \hline
\end{tabular}


Table A2: Selection of sample and attrition

\begin{tabular}{lcccccc}
\hline \hline & \multicolumn{3}{c}{ Round $\mathbf{1}$} & \multicolumn{3}{c}{ Round 2 } \\
& Total & Self & Transporter & Total & Self & Transporter \\
\hline Subject pool & 533 & 313 & 220 & 374 & 209 & 165 \\
New in Round 2 & 0 & - & - & 21 & 13 & 8 \\
Total subject pool & 533 & 313 & 220 & 395 & 222 & 173 \\
- Not found & 156 & 103 & 53 & 3 & 1 & 2 \\
- Second resp. in other HH & 3 & 1 & 2 & 0 & - & - \\
- Refused/Unavailable & 7 & 6 & 1 & 10 & 8 & 2 \\
- No longer supplies & 4 & 3 & 1 & 3 & 3 & 0 \\
- Cows dry next 8 weeks & 0 & - & - & 20 & 12 & 8 \\
- Change to transp. delivery & 0 & - & - & 10 & 10 & 0 \\
- Interviewed & 363 & 200 & 163 & 359 & 188 & 171 \\
(No. of individuals) & $(374)$ & $(209)$ & $(165)$ & & & \\
\hline Excluded from analyses & 6 & 5 & 1 & 4 & 2 & 2 \\
- Cows dry next 8 weeks & 1 & 1 & 0 & 0 & 0 & 0 \\
- No longer supplies & 1 & 0 & 1 & 3 & 1 & 2 \\
- Cannot make decision & 4 & 4 & 0 & 0 & 0 & 0 \\
- Interviewed someone else & - & - & - & 1 & 1 & 0 \\
\hline Analysis sample & 368 & 204 & 164 & 355 & 186 & 169 \\
In administrative data & 346 & 196 & 150 & 319 & 164 & 155 \\
\hline \hline
\end{tabular}

Notes: $\mathrm{HH}=$ household. In the first round, the number in parentheses includes second respondents in the household. The subject pool in round 2 consists of all respondents interviewed at baseline. Respondents who could not be matched with the administrative data did not deliver to Metkei in the study period. 
Table A3: Main results

\begin{tabular}{|c|c|c|c|c|c|c|}
\hline & \multicolumn{6}{|c|}{$\begin{array}{l}\text { Dependent variable: Share of budget } \\
\text { allocated to the early payment date }\end{array}$} \\
\hline & \multicolumn{2}{|c|}{ R2 only } & \multicolumn{2}{|c|}{ R2 only } & \multicolumn{2}{|c|}{$\mathrm{R} 1$ and R2 } \\
\hline & $(1)$ & $(2)$ & $(3)$ & $(4)$ & $(5)$ & $(6)$ \\
\hline Milk payment & $\begin{array}{c}-0.847^{* *} \\
(0.017)\end{array}$ & $\begin{array}{c}-0.847^{* *} \\
(0.017)\end{array}$ & $\begin{array}{c}-0.852^{* *} \\
(0.021)\end{array}$ & $\begin{array}{c}-0.849^{* *} \\
(0.025)\end{array}$ & $\begin{array}{c}-0.864^{* *} \\
(0.024)\end{array}$ & $\begin{array}{r}-0.847^{* *} \\
(0.020)\end{array}$ \\
\hline Budget size (100 kg) & & & $\begin{array}{c}0.008 \\
(0.009)\end{array}$ & $\begin{array}{c}0.004 \\
(0.019)\end{array}$ & $\begin{array}{c}0.016 \\
(0.019)\end{array}$ & $\begin{array}{l}-0.002 \\
(0.010)\end{array}$ \\
\hline Days to early payment/10 & & & $\begin{array}{l}-0.003 \\
(0.004)\end{array}$ & $\begin{array}{l}-0.003 \\
(0.002)\end{array}$ & $\begin{array}{c}0.002 \\
(0.002)\end{array}$ & $\begin{array}{c}0.001 \\
(0.001)\end{array}$ \\
\hline Days between payments/10 & & & $\begin{array}{l}-0.010^{*} \\
(0.004)\end{array}$ & $\begin{array}{l}-0.010^{*} \\
(0.004)\end{array}$ & $\begin{array}{l}-0.002 \\
(0.004)\end{array}$ & $\begin{array}{r}-0.005^{*} \\
(0.002)\end{array}$ \\
\hline Share of milk consumed & & & $\begin{array}{c}0.090 \\
(0.064)\end{array}$ & $\begin{array}{c}0.064 \\
(0.093)\end{array}$ & $\begin{array}{l}-0.005 \\
(0.024)\end{array}$ & $\begin{array}{l}-0.034 \\
(0.026)\end{array}$ \\
\hline First round & & & & & $\begin{array}{l}0.038^{*} \\
(0.019)\end{array}$ & $\begin{array}{c}0.026 \\
(0.017)\end{array}$ \\
\hline$\ldots \times$ higher price & & & & & $\begin{array}{c}0.004^{*} \\
(0.002)\end{array}$ & $\begin{array}{c}0.004^{*} \\
(0.002)\end{array}$ \\
\hline$\ldots \times$ lower price & & & & & $\begin{array}{c}-0.036^{* *} \\
(0.008)\end{array}$ & $\begin{array}{r}-0.036^{* *} \\
(0.008)\end{array}$ \\
\hline$\ldots \times$ offer for 8 weeks & & & & & $\begin{array}{c}-0.024 \\
(0.015)\end{array}$ & $\begin{array}{c}-0.014 \\
(0.015)\end{array}$ \\
\hline Respondent fixed effects & No & Yes & No & Yes & No & Yes \\
\hline Observations & 1,770 & 1,770 & 1,770 & 1,770 & 7,185 & 7,185 \\
\hline Number of respondents & 355 & 355 & 355 & 355 & 396 & 396 \\
\hline$R$-squared & 0.766 & 0.862 & 0.768 & 0.863 & 0.529 & 0.705 \\
\hline Mean dependent variable & 0.207 & 0.207 & 0.207 & 0.207 & 0.083 & 0.083 \\
\hline
\end{tabular}

Note $\mathrm{R} 1=$ Round 1. R2 = Round 2. Estimated using ordinary least squares with standard errors (in parentheses) clustered at the participant level. ' $R$-squared' indicates the explained variation in allocations within respondents. ${ }^{\dagger} p<0.10,{ }^{*} p<0.05,{ }^{* *} p<0.01$ 
Table A4: Logit models

\begin{tabular}{|c|c|c|c|c|c|c|}
\hline & \multicolumn{6}{|c|}{$\begin{array}{l}\text { Dependent variable: At least part of budget/entire budget } \\
\text { allocated to earlier payment date (dummy variable) }\end{array}$} \\
\hline & \multicolumn{3}{|c|}{ Some early } & \multicolumn{3}{|c|}{ All early } \\
\hline & $(1)$ & $(2)$ & (3) & $(4)$ & $(5)$ & $(6)$ \\
\hline Milk payment & $\begin{array}{c}-0.868^{* *} \\
(0.019)\end{array}$ & $\begin{array}{c}-0.888^{* *} \\
(0.018)\end{array}$ & $\begin{array}{c}-0.890^{* *} \\
(0.020)\end{array}$ & $\begin{array}{c}-0.820^{* *} \\
(0.020)\end{array}$ & $\begin{array}{c}-0.736^{* *} \\
(0.193)\end{array}$ & $\begin{array}{r}-0.653^{* *} \\
(0.199)\end{array}$ \\
\hline $\begin{array}{l}\text { Controls } \\
\text { First round allocations }\end{array}$ & & $\checkmark$ & $\begin{array}{l}\checkmark \\
\checkmark\end{array}$ & & $\checkmark$ & $\begin{array}{l}\checkmark \\
\checkmark\end{array}$ \\
\hline $\begin{array}{l}\text { Observations } \\
\text { Number of respondents }\end{array}$ & $\begin{array}{c}1,775 \\
355\end{array}$ & $\begin{array}{c}1,775 \\
355\end{array}$ & $\begin{array}{l}7,295 \\
396\end{array}$ & $\begin{array}{c}1,775 \\
355\end{array}$ & $\begin{array}{c}1,775 \\
355\end{array}$ & $\begin{array}{l}7,295 \\
396\end{array}$ \\
\hline
\end{tabular}

Note Displayed are marginal effects, estimated using a logit model with standard errors (in parentheses) clustered at the respondent level. Controls are the budget size, the number of days to the early payment, the number of days between early and late payments, and the self-reported share of milk consumed yesterday as control variables. In addition, Columns (3) and (6) also control for dummy variables indicating first-round allocations, and dummy variables interacting this variable with the price scenario and an indicator for the eight-week offer. ${ }^{\dagger} p<0.10,{ }^{*} p<0.05,{ }^{* *} p<0.01$. 
Table A5: Expected production vs. actual deliveries

\begin{tabular}{|c|c|c|c|c|c|c|}
\hline & \multicolumn{6}{|c|}{ OLS. Dependent variable: Share of budget allocated to early payment } \\
\hline & $\begin{array}{l}\text { Expected } \\
\text { (R1) }\end{array}$ & $\begin{array}{c}\text { Delivered } \\
\text { (R1) }\end{array}$ & $\begin{array}{c}\text { Expected } \\
\text { (R1) }\end{array}$ & $\begin{array}{c}\text { Delivered } \\
\text { (R1) }\end{array}$ & $\begin{array}{l}\text { Expected } \\
(\mathrm{R} 1+\mathrm{R} 2)\end{array}$ & $\begin{array}{c}\text { Delivered } \\
(\mathrm{R} 1+\mathrm{R} 2)\end{array}$ \\
\hline & $(1)$ & $(2)$ & $(3)$ & (4) & $(5)$ & (6) \\
\hline Milk payment & $\begin{array}{c}-0.835^{* *} \\
(0.019)\end{array}$ & $\begin{array}{c}-0.833^{* *} \\
(0.019)\end{array}$ & $\begin{array}{c}-0.840^{* *} \\
(0.023)\end{array}$ & $\begin{array}{c}-0.857^{* *} \\
(0.023)\end{array}$ & $\begin{array}{c}-0.831^{* *} \\
(0.023)\end{array}$ & $\begin{array}{c}-0.836^{* *} \\
(0.024)\end{array}$ \\
\hline Budget size (100 kg) & & & $\begin{array}{c}0.007 \\
(0.010)\end{array}$ & $\begin{array}{c}0.017 \\
(0.013)\end{array}$ & $\begin{array}{l}-0.007 \\
(0.012)\end{array}$ & $\begin{array}{c}0.001 \\
(0.014)\end{array}$ \\
\hline Days to early payment/10 & & & $\begin{array}{l}-0.002 \\
(0.004)\end{array}$ & $\begin{array}{c}0.004 \\
(0.005)\end{array}$ & $\begin{array}{c}0.001 \\
(0.001)\end{array}$ & $\begin{array}{c}0.001 \\
(0.001)\end{array}$ \\
\hline Days between payments/10 & & & $\begin{array}{c}-0.010^{*} \\
(0.005)\end{array}$ & $\begin{array}{c}-0.011^{*} \\
(0.005)\end{array}$ & $\begin{array}{c}-0.005^{*} \\
(0.003)\end{array}$ & $\begin{array}{c}-0.007^{* *} \\
(0.002)\end{array}$ \\
\hline Share of milk consumed & & & $\begin{array}{c}0.127 \\
(0.083)\end{array}$ & $\begin{array}{c}0.159^{\dagger} \\
(0.093)\end{array}$ & $\begin{array}{l}-0.037 \\
(0.038)\end{array}$ & $\begin{array}{c}0.008 \\
(0.042)\end{array}$ \\
\hline Additional controls & No & No & No & No & Yes & Yes \\
\hline Observations & 1,534 & 1,534 & 1,534 & 1,534 & 6,391 & 6,391 \\
\hline Number of respondents & 319 & 319 & 319 & 319 & 369 & 369 \\
\hline R-squared & 0.751 & 0.735 & 0.754 & 0.739 & 0.766 & 0.799 \\
\hline Mean dependent variable & 0.212 & 0.214 & 0.212 & 0.214 & 0.083 & 0.071 \\
\hline
\end{tabular}

Note R1 = Round 1. R2 = Round 2. OLS = ordinary least squares. Standard errors in parentheses, clustered at the respondent level. The analyses include all allocations that could be matched to administrative delivery data. Columns (5) and (6) control for a first-round dummy interacted with the price scenarios and an eight week-offer dummy. ${ }^{\dagger}$ $p<0.1,{ }^{*} p<0.05,{ }^{* *} p<0.01$ 
Table A6: Stated uses of income from selling milk yesterday

\begin{tabular}{lccccccccc}
\hline \hline & \multicolumn{3}{c}{ Full sample } & \multicolumn{2}{c}{ Same resp. } & \multicolumn{2}{c}{ Full sample } & \multicolumn{2}{c}{ Same resp. } \\
\hline & Co-op & Other & Co-op & Other & a.m. & p.m. & a.m. & p.m. \\
Food \& daily expend. & 28.97 & 90.72 & 16.28 & 89.53 & 28.62 & 82.88 & 18.56 & 83.51 \\
School fees & 61.99 & 7.22 & 66.28 & 6.98 & 61.95 & 9.91 & 63.92 & 8.25 \\
Dairy \& crop expend. & 64.17 & 17.53 & 70.93 & 17.44 & 65.41 & 18.02 & 73.20 & 18.56 \\
\hline Respondents & 321 & 97 & 86 & 86 & 318 & 111 & 97 & 97 \\
\hline \hline
\end{tabular}




\section{RECENT IFPRI DISCUSSION PAPERS}

\section{For earlier discussion papers, please go to www.ifpri.org/publications/discussion papers. All discussion papers can be downloaded free of charge.}

1645. Climate change and variability: What are the risks for nutrition, diets, and food sstems? Jessica Fanzo, Rebecca McLaren, Claire Davis, and Jowel Choufani, 2017.

1644. Building resilience for food systems in postwar communities: Case study and lessons from Northern Sri Lanka. Hamsha Pathmanathan, Suresh Chandra Babu, and Chandrashri Pal, 2017.

1643. Empowerment, adaptation, and agricultural production: Evidence from Niger. Fleur Wouterse, 2017.

1642. Insurance structure, risk sharing, and investment decisions: An empirical investigation of the implications of individual and group weather index insurance. Laura Munro, 2017.

1641. Economic accounts for agriculture and farm income in Senegal. Ismaël Fofana, Mahamadou Tankari, and Fousseini Traore, 2017.

1640. Food inflation and food price volatility in India: Trends and determinants. C. S. C. Sekhar, Devesh Roy, and Yogesh Bhatt, 2017.

1639. Revitalized agriculture for balanced growth and resilient livelihoods: Toward a rural development strategy for Mon State. Mateusz Filipski, Ulrike Nischan, Joanna Van Asselt, Ben Belton, Adam Kennedy, Aung Hein, Duncan Boughton, and Paul Dorosh, 2017.

1638. Rural livelihoods in Mon State: Evidence from a representative household survey. Mateusz Filipski, Joanna Van Asselt, Ulrike Nischan, Ben Belton, Kyan Htoo, Myat Thida Win, Aung Hein, L. Seng Kham, Zaw Min Naing, Ellen Payongayong, and Duncan Boughton, 2017.

1637. The great Chinese inequality turnaround. Ravi Kanbur, Yue Wang, and Xiaobo Zhang, 2017.

1636. Can agricultural aspirations influence preferences for new technologies?: Cropping systems and preferences for highefficiency irrigation in Punjab, Pakistan. Andrew R. Bell, Patrick S. Ward, Muhammad Ashfaq, and Stephen Davies, 2017.

1635. Impact of India's national food security act on domestic and international rice markets. Deepayan Debnath, Suresh Chandra Babu, Parijat Ghosh, and Michael Helmar, 2017.

1634. Agricultural diversification in Nepal: Status, determinants, and its impact on rural poverty. Ganesh Thapa, Anjani Kumar, and P. K. Joshi, 2017.

1633. The "discouraged worker effect" in public works programs: Evidence from the MGNREGA in India. Sudha Narayanan, Upasak Das, Yanyan Liu, and Christopher B. Barrett, 2017.

1632. Measuring postharvest losses at the farm level in Malawi. Kate Ambler, Alan de Brauw, and Susan Godlonton, 2017.

1631. Nutrition transition and the structure of global food demand. Christophe Gouel and Houssein Guimbard, 2017.

1630. Insuring against droughts: Evidence on agricultural intensification and index insurance demand from a randomized evaluation in rural Bangladesh. Ruth Vargas Hill, Neha Kumar, Nicholas Magnan, Simrin Makhija, Francesca de Nicola, David J. Spielman, and Patrick S. Ward, 2017.

1629. Nutrition incentives in dairy contract farming in northern Senegal. Tanguy Bernard, Melissa Hidrobo, Agnes Le Port, and Rahul Rawat, 2017.

1628. Chinese investment in Ghana's manufacturing sector. Xiaoyang Tang, 2017.

1627. Participation, learning, and equity in education: Can we have it all? Clara Delavallade, Alan Griffith, Gaurav Shukla, and Rebecca Thornton, 2017.

1626. Limitations of contract farming as a pro-poor strategy: The Case of maize outgrower schemes in upper west Ghana. Catherine Ragasa, Isabel Lambrecht, and Doreen S. Kufoalor, 2017.

1625. Cooperation in polygynous households. Abigail Barr, Marleen Dekker, Wendy Janssens, Bereket Kebede, and Berber Kramer, 2017.

1624. Farmers' quality assessment of their crops and its impact on commercialization behavior: A field experiment in Ethiopia. Gashaw Tadesse Abate and Tanguy Bernard, 2017. 
INTERNATIONAL FOOD POLICY

RESEARCH INSTITUTE

www.ifpri.org

IFPRI HEADQUARTERS

1201 Eye Street, NW

Washington, DC 20005 USA

Tel.: +1-202-862-5600

Fax: +1-202-862-5606

Email: ifpri@cgiar.org 